\title{
The Balé Lady: Relationships between machines and emotions
}

\author{
Keywords \\ Machines; Emotions, Creation Process, Orixás.
}

This work is the result of the master's research, "Machines and Emotions in Art". By the machines, the intermediaries of technology emerged, by the emotions, the biological and human semantic complexities came up, created a labyrinth for the development of the theoretical research. However, it was only the artistic processes that brought the flexibility to connect the reflections studied in the theories, from such different fields of knowledge, and resulted in the exhibition the "Senhora do Balé", 2019. In Brazilian popular culture the Yoruba word "Balé" refers to cemeteries and/or the cult of the dead. The title of the exhibition is related to lansã, orixá lady of the winds and storms and who takes care of the disembodied souls. The Orixás are deities, saints and gods, who relate the forces of nature and human characteristics and are present in the Brazilian religions and myths of African matrices, such as Candomblé and Umbanda. The orixas are the defenders of the minds and have their origins in the Yoruba people, originally from western Africa. Their stories, origins, and myths have many meanings, for being present in different places, families and traditions. Besides lansã, the orixás are approached in the materiality of the works, with the use of iron, an element of Ogum, orixá of technology. These artworks are a metaphysical relationship which approximated machine graveyards with the human relationships with their ancestors. The initial objectives of the proposition were to elaborate an inventory of artistic works that presented machines with an anthropomorphic character, as in the artistic works of the artist Zaven Parè. but before arriving at this approximation of the machine as a human form and considering the whole elaborated path, a type of machine stood out, the machine tools, and along with them, human relations with tools. and evaluating these tools, their materiality, found in different fields of everyday life, the idea of creating machines was synthesized into elements of tools. In this way, the artworks were proposed as being machines in a metaphorical way. They worked interactively in a direct way or only through the shadows of the interactors, without using large motors or very complex automatic systems. It was assumed that emotions are imbricated in levels that a machine can develop, in the possible narratives, considering the faculty of design as the link between human creation and the coexistence with technical devices. To this end, objects that are machines and that are works of art were projected, transforming the theoretical research into an artistic work, into narratives, into poetry, into art, which permeates a daily experience that was reflected in the gallery, populated with objects, machines, shadows and lights. This work is full of paradoxes, because the scientific universe does not allow artistic experiments so easily. Thus, this presentation brings a descriptive memorial of the creation of the artworks/machines that make up the exhibition and that was the result of theoretical research, but also of the everyday life of the studio. 